THE MUSCLE-SPINDLE ${ }^{1}$ UNDER PATHOLOGICAL CONDITIONS.

\author{
BY FRED. R. BATTEN, M.D.
}

From the Pathological Laboratory of the National Hospital, Queen Square.

Aцtнобян the existence of the spindle in muscle has long been known, and a considerable amount of literature has been accumulated by continental writers, yet antil a publication by Sherrington (30) in the Journal of Physiology, the subject had received but small attention in England. Beale (2), indeed, in 1862, gave an accurate description of the spindle, but regarded it as muscle and nerve in the course of development. It is my parpose, therefore, in the following paper :-

(I.) To gire a short account of the work already done on the muscle-spindle.

(II.) To enumerate the various views that have been held with regard to the origin and function of the musclespindle.

(III.) To give a short account of the methods I have found to be usefal.

(IV.) To give a description of the muscle-spindle as found in man.

(V.) To demonstrate the condition of the muscle-spindle under the following pathological conditions:-

(1) Infantile paralysis.

(2) Tabes.

(3) Myopathy.

(4) Progressive muscular atrophy.

(5) Peripheral neuritis.

(6) Injury to the Brachial plexus.

(7) After section of the sciatic nerve in cats.

' Symonyms Mískelknospen, umschnûrte Bündel, Faisceanr neura-muscalaires, Neuritis fascians, Neuro-musoulese Strimmchen. 


\section{(I.) History.}

In 1843, Miescher (21) described, in the abdominal muscles of a house monse, bodies to which he gave the name of Schläuchen. V. Siebold (31) figares these in a peper published in 1853, and states that the same bodies have been found in rats. Miescher thought they were pathological or a parasite, a view which v. Siebold, however, negatives. It seems to me not improbable that these were bodies which one now knows as muscle-spindles.

In 1861, Weismann (37), working with the mascle of frogs, described very fine muscle fibres in groups of six, eight, ten, or more. The diameter of these fibres varies considerably. They are bound together by a cord about the centre of their course, and, indeed, appear to be enveloped in a dull granular substance, through which one can but indistinctly trace each fibre; these fibres are equal in length and reach from tendon to tendon. Weismann considers these fibres as a stage in the development of muscle.

In 1862, Kölliker (18) described his Muskelknöspen which he found in the muscle of frogs, and he believed them to be muscle in the process of division. In his Croonian Lecture, 1862 (18), he says that though at first sight these bodies appear to be of the nature of tactile corpuscles or terminal nerve bulbs, they do not really belong to that class of body. They are nodular swellings marked by a profusion of rather roundish nuclei, and receiving a single very thick nerve fibre loosely surrounded by its comparatively wide membranous sheath. On further examination it is found that the nerve fibre, on reaching the nodales of the muscle, is wound up into a coil, in the meantime undergoing repeated division, and it may be seen to enter the muscle fibre.

On carefal examination, howerer, it is found that the apparently simple muscular fibre is really a small bandle of tbree to seven fibres, and that the penetrating nerve fibres pass between these muscle fibres. Simultaneously with the increase of its terminal fibres, the dark-bordered parent nerve fibre doubtless augments in thickness, which explains the fact, otherwise difficult to understand, that it is invariably of 
much larger size than the nerve fibres proceeding to the other musculer fibres.

In 1889 (18), Kölliker hed stadied the muscle-spindle not only in frogs, but also in rabbits and man, and after discussing the various views held with regard to these bodies, he still holds that they are muscle in the course of development.

In 1862, Beale (2), in a paper on the distribution of nerves to the elementary fibres of striped muscle, gives a detailed description of these bodies, and regards them as mascle and nerve in the coarse of development, and it is from observation of these that this author comes to the conclusion that the muscle fibre is supplied with nerves in its entire length.

In his Croonian Lectures, 1865 (2), he further considers these bodies, holding the same view and differing only from Kolliker in that he believes the development of the musclefibres takes place from the nuclei and not by division of the parent fibre.

Kühne (19), in 1863, working with the muscle of white rats, described a nerve dividing into two branches and entering a spindle-shaped muscle, where it ended in clear, transparent bodies, the nerve actually ending in a distinct hillock. In a more detailed paper on "Die Muskelspindeln" (19), he says that the above-described endings correspond with the browd nerve fibres. The proportion of spindles to muscle fibres is about 1-100 (in house mouse), and he farther remarks that the abdominal and thoracic muscles seem to bave more than the extremities. The nerve fibres passing to the spindles are three or four times as broad as those to motor nerve-endings. Each spindle is, as a rule, supplied by two nerves which come from a common trunk, the sheath of the nerve fibre passing into the sheath of the spindle. The muscle fibres of the spindle are smaller than the neighbouring fibres, and have well-marked striations at the ends, but lose these towards the centre; the striation of the muscle is broader than in the larger fibres, but this is asually the case with the smaller fibres. In conclusion he says: "It would seem from the above that a knowledge of the muscle-spindle is of great importance in 
anderstanding the development, regeneration, and the growth of muscles and their nerves.

In a further paper (19), pablished in 1864, he says: " Are they an apparatus with a peculiar, still unknown physiological function for the Zuckungsvorgang des Gesammtmuskels, or are they only a stage in the not yet completely developed muscle fibre?"

Peremeschko (23), in 1863, in stadying the development of striated muscle, discusses the spindle described by Kühne, denies that a nerve enters them, and agrees with Kölliker in calling them Muskelknöspen.

Sachs (28), in 1874, in a series of papers on the sensory nerves of muscles, shows that in frogs after section of the anterior roots for a period of six to eight weeks the motor fibres were completely degenerated, on the other hand the nerve in the muscle contained two well-formed, brosd, medullated fibres, which after dividing gave off coarse nerve twigs; the further distribution of these differed entirely from the condition of a motor nerve.

$\mathrm{He}$ then discusses the result of section of the posterior roots peripherally to the ganglion. The degeneration of the sensory muscle nerves takes places very slowly, and after six weeks the appearance is by no means striking, and on this point he comes to no definite conclusion. He describes the nerve entering a spindle-shaped body and twisting round the muscle fibre in a spiral form.

Eisenlohr (9), in 1876, described, in a case of infantile paralysis, a small number of well-preserved fibres arranged within a sheath which they incompletely fill. $\mathrm{He}$ does not seem to have recognised them as spindles in cross section and would seem to regard them as pathological.

Fraenkel, in 1878 (13), in an exhaustive paper on the changes in the muscle of phthisical patients, describes " amschnürte Bündel" situated generally in the neighbourhood of vessels and nerves. He considers them pathological. He gives measurements of these bundles and there is no doubt that he is describing the muscle-spindle in transverse section. He states that he has never found them in the muscles of the eyes, never in the disphragm or masseter, but they are 
abandant in the mascles of the thamb. He found these " umschnürte Bündel " in one-third of all his preparations.

Ranvier (25), in 1878, discussing the spindles described by Kühne, says that they are cylindrical in shape. He notes that the muscle fibre loses its striation and becomes granular, shiny, and contains several nuclei at one part. He calls attention to the resemblance of the sheath to that of a Pacinian body. He says the nerve, after penetrating the sheath, divides into two; some fibres pass between the layers of the sheath, others either pass along a muscle fibre or curl spirally round it. He does not know whether they should be considered mascle fibres in the course of development or fibres undergoing atrophy.

Millbacher (22), in 1882, examined muscles in tbirty cases of acute and chronic disease; he, like Fraenkel, found the "umschnürte Bündel" in about one-third of all his preparations; he, too, never found them in the eye muscles, diaphragm or masseter, being abundant, however, in the thumb. He describes three forms of " umschnürte Bündel " :

(i.) Unvollständig amschnürte Bündel ;

(ii.) Vollständig umschnürte Bündel, containing mascle fibres;

(iii.) Vollständig umscinnürte Bündel, containing atrophied fibres;

and in these three forms he sees the process of degeneration. He found them also in four cases of apparently healthy individuals, and in these cases he is doubtful of their significance.

Golgi (15), in 1882, describes a spindle and gives drawings in cross and longitudinal sections. Why these fibres lie imprisoned and preserve, even in odult life, the characters of imperfectly developed fibres is not clear. He suggests that they have some special connection with the lymphatic system.

Bremer (4), in 1883, working with the muscles of frogs, mice and lizards, believes that muscle-spindles are a stage in the development of muscle, and he traces the various steps in development, not only of the muscle, but also of the end 
plate. He notes the large size of the nerve fibre entering the spindle and its thick sheath; he notes that the muscle fibre loses its striation near the centre of the spindle. He gives a detailed description of the spindle, and associates the variation in the spindle with various stages of development.

Babinski (1), in 1884, described, in the muscles from a case of chronic myelitis, circular rings having in their centre several atrophied fibres. He considered them as pathological. In a further paper, published in 1886 , he gives a description of the spindle in transverse section, having a dismeter of 100 to $200 \mu$; he says the spindle generally contains three to seven fibres; he notes the sub-division of the intrafasal space, one part conveying the vessels, another the nerve, and the third the muscle fibres. He no longer considers them as pathological, but is doubtfal of their real meaning. In a third paper, published in 1889, he criticises Eichhorst's " Neuritis fascians."

Mays, in 1884, studying the distribution of nerves in the muscles of frogs by means of the gold chloride method, describes certain appearances which he compares to the muscle-spindles of Kühne; he believes they are in connection with the sensory nerve fibres.

In 1892, in a paper on the development of the motor nerve endings, he expresses the opinion that muscle-spindles take no part in the development of muscle.

Roth (26), in 1887, published, under the heading "Neuromusculaire stämmchen," a description of a muscle-spindle. He had found them first in atrophied muscle, and soon after in healthy muscle. He considers them as physiological organs.

Westphal (39), in 1887, in two cases of pseudo-hypertrophy in sisters, describes small groups of muscles surrounded by connective tissue occurring in muscle which was completely atrophied; he does not seem to recognise them as muscle-spindles.

Eichborst (8), in 1888, describes, under the heading "Neuritis fascians," certain structures he has noted in the muscles from a case of alcoholic neuritis. He describes the onion-like sheath of the spindle, and believes that it comes from the thickened sheath of the nerve. 
Felix (11), in 1888, working with the muscle of fœtuses from the fourth month to the thirty-sixth week, describes "primitive muscle bundles"; these are characterised by (1) greater breadth, (2) more intense staining, (3) wider striation, (4) marked Henle sheath. Nuclear increase is marked at one part of the muscle fibre, and tracing a primitive bandle one sees (1) an increase of irregularly-arranged nuclei, (2) nuclei arranged in rows; usually three rows of nuclei are found, the primitive bandle here beconing widened to nearly three times its former diameter. Only once did be find a nerve near, and he doubts whether they had any connection; he compares them to the muscle-spindles of the frog. In a further paper (11), in 1889, studying the growth of striated muscle in man, he points out that in the adult musclespindle there are usually three to six muscle fibres, whereas in the fotal spindle there may be as many as twenty; this he attributes to the division of the daughter fibres. The sheath of the spindle is characteristic, and passes gradually into the perimysium of the muscle, so that on section towards the end of a spindle there is nothing to call attention to the presence of a spindle. He believes that spindles are most frequently found near the tendon, and, as may be inferred from the above, he considers them as a stage in the development of muscle.

Cattaneo (5), in 1888, studying the musculo-tendon nerve termination described by Golgi, both under normal conditions and after experimental lesions in guinea-pigs, rabbits, cats, and dogs, describes a body having a length of 80 to $800 \mu$. situated generally where the muscle passes into the tendon, one extremity of the organ passes into the tendon the other into the muscle. The sheath enclosing these resembles the Henle sheath of a nerve. A nerve enters this body, and after passing through the sheath divides into two; the mode of termination is described. Blood vessels can also be seen entering this body. Among these musculo-tendon organs one can sometimes see a muscle-spindle, such as has been described by Kölliker, and after discussing various views, he is inclined to agree with him (Kölliker) rather than with Millbacher and Kraske, who regard them as pathological.

He has seen the mascle-spindle lie between two of the 
musculo-tendon organs, but the nerve supplying the spindle arrives from a different direction. There is, however, a certain analogy between the two. With regard to the function of these muscalo-tendon organs, after discussing the point at some length, he says that if they are the organs of muscular sense they ought to be independent of motor nerve fibres, and to be intimately connected to sensory fibres. To answer this question two paths are open: (1) the pathological, (2) the experimental. Not having the opportanity for the first, he turns to the second.

In dogs, after section of the posterior roots (fifteen days to four months), ataxia was found to be present, but he could find no alteration in the musculo-tendon organs nor in the muscle fibre.

In dogs in whom the anterior roots were cut the musculotendon organs remained normal ; the muscle itself, however, showed advanced atrophy.

After complete section of the nerve, changes were found in the terminal organs 36 to 38 hours after section.

In conclusion, he says that the musculo-tendon organs are found sometimes in contact with muscle-spindles, sometimes with Pacinian bodies, but the position of the nerve fibre proves them to be independent of these bodies.

He considers the musculo-tendon organs above described as the true organs of muscular sense.

$\mathrm{He}$ further adds that, after section of the nerve, degeneration of the medullated portion of the nerve is slow, whereas in the non-medullated part it occurs in 20 hours, and disappears in three to four days.

Siemerling (32), in 1888, in a paper on a case of gumma of the base of the brain, describes what he considers to be a spindle in the inferior rectus of the eye, which muscle had undergone considerable atrophy.

In a second paper he criticises Eichhorst's "Neuritis fascians," and in a third (32) he reports a case of alcoholic neuritis, and says that the spindle seems to enjoy a certain immunity against pathological changes. This is not always so, however, for in two cases of phosphorus poisoning he found the muscle fibres of the spindle filled with fat globules. 
Kerschner (17), in 1888, after describing the musclespindle, says that the spindle frequently ends in the connective tissue, and suggests that the function of the spindle might be to protect the nerve-ending; he comes, however, to the conclusion that they are a complicated sensory organ which may serve muscular sense. In a further paper (17) he compares muscle-spindles with other sensory end organs found in joints, tendons, conjunctiva, tongue, \&c. In 1892, von Ebner (17) showed for Kerschner certain specimens to demonstrate the nerve-ending within the spindle stained with gold chloride; two nerve-endings are described, one a motor on the muscle fibre, another sensory, twined round the muscle fibre. In support of the sensory nature of these organs he puts forward the following points :-

(i.) The abundant nerve supply, far above the number of muscle fibres.

(ii.) The division of the nerve fibre after a type which reminds one more of a sensory than of a motor ending.

(iii.) The presence of nuclear groups like those of endbulbs.

(iv.) The frequent ending of part of the same nerve in a tendon organ.

(v.) The analogy with a Golgi organ: (a) supply from the same nerve; $(\beta)$ similar sheath.

(vi.) Their constant presence ; their number and appearance in many muscles in which fine mascular sense is needed.

(vii.) The apparent vicariousness of the Golgi organ in similar muscles, as in the muscles of the eye. ${ }^{1}$

Kerschner then enters into the various points that have been advanced in proof of the embryological characters of the spindle, viz., the darker staining, the abundant nuclei, the variations in the sheath, and the presence of double and quadraple spindles. He says the darker staining frequently occurs with the smaller muscular fibres, the abundant nuclei occur at the nerve entrance, and the variations of the sheath are dependent on the point at which it is cut across. He points out that mitosis is absent. The one point which he

'Comp. Marchi, Archiv fïr Ophthalmologie, xuviii, , 1882, and Journal of Physiology, rol. xrii., p. 248. 
agrees looks like a developmental process is the division of the spindle into two and sometimes into four. In a further paper (17), 1893, he sums up the views held at that date by various authors.

Pilliet (24), in 1890, described the presence of musclespindles in the muscles from cases of alcoholic paraplegia, chronic rhenmatism, and amyotrophic lateral sclerosis. He says it would seem that atrophy of the mugcle makes them apparent.

Blocq and Marinesco (3), in 1890, showed that in a case of poliomyelitis and another of polyneuritis that the muscle spindles existed when there was total loss of all other muscle fibres.

Von Franque (14), in 1890, maintains the view that the muscle-spindle is a stage in the development of muscle.

Santesson (29), in 1890, describes the muscle-spindle in a case of myopathy (Leyden's form), and regards them as pathological appearances.

Dogiel (7), in 1890, studying the motor nerve-endings in the mnscles of frogs, \&c., by staining them with methylene blue, describes the entrance of the nerve into a musclespindle. The chief fibre to the spindle he describes as dividing into two-(i.) winds in the spindle in a spiral form and (ii.) distributes itself to the spindle sheath.

Christomanos and Strössner (6), in 1891, studying the spindle under normal circumstances in a fotas, a new-born child, a child nine years old, and in an adult, found them in all of them, and they give a table showing the comparative size of the intra- and extrafusal muscle fibres. They describe an inner and outer sheath, and note that the spindle is larger in adults than in children, the increase being due chiefly to the thickness of the wall. They consider the spindle to be a sensory organ.

Trinchese (35), in 1891, sums up what is known of the muscle-spindle; he refers to his own work in 1888, when he demonstrated that the spindles had a different form and structure at the various periods of their development. He describes the nerve entering the nucleated part of the muscle fibre, and finishes by stating that the assertion of Bremer 
that these fibres are muscle fibres in the coarse of development has not yet been demonstrated as being true. It would, indeed, seem probable, but until the phase of transition between the adult muscle fibre and the spindle has been demonstrated it cannot be asserted positively what the nature of these organs is.

Erb (10), in 1891, describes a bundle of small fibres surrounded by a nucleated, definitely striated band, which does not completely surround these fibres (p. 94), and in relation to the regeneration taking place in a degenerated muscle, he says that the foregoing curious condition stands in close relation to the Muskelknöspen (p. 147).

V. Thanhoffer (34), is 1892, asserts that the so-called muscle-spindles are nothing more than "building material" for the regeneration of muscle and nerve fibres.

Volkmann (36), in 1893 , studying the regeneration of striated mascle, says he has found the muscle-spindle in four cases-(i.) the thumb muscle after injury to the arm, (ii.) diphtheritic paralysis, (iii.) in rectus abdominis of man aged 40 , and (iv.) in the hand of a man who died of spinal disease. He believes that these bodies have to do with the growth of muscle, and not with regeneration of muscle.

Ruffini (27), in 1893, compares the muscle-spindles as found in cats with those found in man. He gives a description of the various terminations, and states that the annulospiral termination present in the cat is not found in man. The termination a fleurs is present in both, but is more numerous in man. In conclusion, he says that one may regard these fuseaux musculaires as special nerve organs, having a fanction anknown.

Forster (12), in 1894, working with the ruscle from cases of muscular atrophy, transverse myelitis, \&c., found that in muscles which were completely degenerated the muscle fibre inside the spindle remained well preservedthe nerve fibre passing to the spindle being also well preserved, as shown by Weigert's staining. It would seem that the trophic centre for the spindle does not lie in the spinal cord, and it is suggested that it lies in the spinal ganglion. Muscle-spindles are considered as a physiological apparatus, 
and the suggestion of Kerschner is followed, viz., that they serve muscular sense.

Sherrington (30), in 1895, examined muscle in which all the motor fibres had been divided and the muscle fully degenerated; he found that the spindle remained intact, the nerve fibre passing to it was well-preserved and could be traced to the sensory roots. The intrafusal fibres were well preserved, the striation well marked.

Further, in a cat in whom the sciatic had been divided for 150 days, the muscle was completely degenerated; with regard to the spindle, the nerve fibres passing to it were degenerated, and the spindle itself contained globules of fat, but the intrafusal muscles were well preserved and their striation well marked. It would seem, therefore, that the intra-fusal muscle fibres are independent, in regard to their nutrition, both of afferent and efferent fibres.

Sihler (33), in 1895, published a method of staining spindles with hæmatoxylin. In the same year be published the results of his investigations in snakes and frogs. $\mathrm{He}$ gives a detailed account of the spindles, and considers them to be sensory organs.

Weiss and Dutil (38), in 1896, working with the muscle of rabbits, cats, \&c., and using by preference the gold chloride method described by Ranvier, describe three modes of nerve termination within the spindle:

(i.) Two fine branches, one passing above, and the other below, a nucleus.

(ii.) A small eminence on the sarcolemma, where there is a group of two to three nuclei. This ending is generally found toward the pole of the spindle.

(iii.) Fibres spread themselves on the surface of the muscular bundles in tree-like form, deprived of all nuclear elements.

They arrive at the conclusion that spindles are sensory in function, and probably have the same function as Golgi's tendon organs.

Gudden (16), in 1896, says that in alcoholic neuritis the muscle fibres in the neuro-musculaere Stämmchen are degenerate, and that the nerves within the spindle do not stain normally. 
(II.) Theories With regard to Origin and Function OF THE MUSCLE-SPINDLE.

From the above abstract it will be seen that various views have been held as to the origin and function of the musclespindle, and I would here simply enumerate them.

(i.) That the muscle-spindle is muscle and nerve in a stage of development.

(ii.) That the muscle-spindle is muscle in the state of degeneration; (a) physiological ; $(\beta)$ pathological.

(iii.) That the muscle-spindle is a sensory nerve-ending in muscle.

(iv.) That the muscle-spindle is a protection to the nerveending during contraction of the muscle.

(v.) That the muscle-spindle has special connection with the lymphatic system.

I do not propose in this paper to enter into a discussion of these theories, all of which are dealt with at some length in the papers above quoted.

I believe, however, that all the evidence at present points to the fact that the muscle-spindle is the organ from which muscular afferent impulses are derived. Closely allied to the muscle-spindle are the musculo-tendon organs, and the tendon organs situated respectively between the muscle and the tendon and in the tendon.

What the exact nature of the impulses derived from these organs may be seems to me at present uncertain, bat I think that the suggestion of Kerschner with regard to the musclespindle, by Cattaneo with regard to the musculo-tendon organ, that they are connected with the sense of position, may well receive consideration.

\section{(III.) Methods.}

I have used the following methods and stains in my work :

As often as possible portions of muscles have been hardened in Müller's fluid (some specimens which had been in spirit for some time were not put into Müller's fluid). 
Small pieces were then placed in Marchi's solution for five to six days, washed in water, placed in alcohol and embedded in celloidin-some were, however, embedded in wax, cut and mounted in series.

\section{Staining.}

(i.) Specimens were mounted without further staining.

(ii.) Others were stained with hæmatoxylin and eosin.

(iii.) Others were stained by Pal's method.

The method, however, which I have found of most service is that described by Sihler (33).

A portion of fresh muscle is taken, and I find it best to select a part near the entrance, or slightly below the entrance, of a nerve. Divide this longitudinally into pieces the size of a small pencil, or, as I have found very convenient, freeze the tissue and cut thick sections in the direction of the muscle-fibre put these into the following solution :

$\begin{array}{lllll}\text { Acetic acid } & \ldots & \ldots & \ldots & 1 \text { part } \\ \text { Glycerine } & \ldots & \ldots & \ldots & 1 \text { part } \\ \begin{array}{c}\text { Chloral bydrate solution, } \\ \text { in distilled water }\end{array} & \ldots & \text { per } & \text { cent. } & \\ \quad \ldots & \ldots & 6 \text { parts }\end{array}$

Let the tissue remain in this solution for twenty-four hours, then saturate with glycerine for two to three hours. The tissue is then swollen up, and can easily be pulled apart into fine strands about the size of a pin (if the tissue has been cat on a freezing microtome this is not necessary), which are placed in the following solution for three to ten days :

Ehrlich's hæmatoxylin $\quad . . \quad$... 1 part

$\begin{array}{lllll}\text { Glycerine } & \ldots & \ldots & \ldots & 1 \text { part }\end{array}$

Chloral hydrate sol. 1 per cent. in distilled water $\quad$... $\quad$... 6 parts

Pieces of muscle are now removed, placed between two slides and squeezed; on holding the specimen up to the light, or on looking at it ander a low power of the microscope, a spindle-shaped body can often be seen stained darker than the surrounding muscle fibre. It will be noticed, too, that 
the nerves, vessels, and lymphatics are also stained darker than muscle tissue. The spindle can now be teased out under the low power of the microscope, or even without the aid of any magnifying power.

In searching for the spindle it is always a good plan to follow a nerve fibre, as it frequently happens that such a fibre guides one to a spindle.

Having separated out a spindle, it can now either be mounted in the usual way or, if overstained, treated with dilute acetic acid-or after washing in water can be put to harden in Müller's fluid.

After hardening in Müller's fluid till all colour has disappeared from them, they can be placed in Marchi solution, treated in the usual way, and embedded in celloidin, and cat either longitudinally or transversely in series. The sections can then be stained by Pal's method, and a counter stain, dehydrated, and mounted in series. Specimens hardened in the above method, and mounted without further staining, show any recent degeneration.

Many of the series have been cut in wax, but I have experienced great difficulty in staining a spindle by Pal's method as a whole, and by far the most satisfactory results are obtained by cutting in celloidin and staining each section separately. The embedding in wax is, however, very useful for pieces of muscle stained with carmine or with Marchi solution, which do not require further staining.

(IV.) The Nurmal Muscle-spindle as Found in Man.

Distribution.-Muscle-spindles have been found in nearly all muscles of the body, but they are by no means evenly distributed. They are certainly numerous in the small muscles of the hand, and in the biceps of the arm (the latter muscle I have used more often than any other one muscle). Forster (12) states that they are frequent in the extrinsic muscle of the larynx. I have been unable to find them in the muscles of the eye, the intrinsic muscles of the tongue, or in the diaphragm, but my examination of these muscles 
has been by no means exhaustive. The above statement agrees with that of other authors, Fraenkel (13), Millbacher (22), Kerschner (17), and Sherrington (30); but, with regard to the eye, is at variance with the statement of Siemerling (32), who has described a spindle in an atrophied inferior rectus muscle of the eye; and in regard to the tongue is at variance with a statement of Forster's (12), that they are to be found in the hinder part of the tongue.

Further, the muscle-spindles are more frequent in the belly of the muscle than near the tendon, but in relation to this statement it would seem to me that we should recognise in the muscle-spindle, in the muscalo-tendon organ, and in the tendon organ the gradual transition from the one organ into the other, and I would regard them, not as distinct organs, but as variations of the same organs adapting themselves to the tissue in which they are situated, and in all probability serving the same function.

Age.-Muscle-spindles occur at all ages, from the fourth month of foetal life onwards; this has been shown by Felix (11), Siemerling (32), and Christomanos and Strössner (6).

Size.-The size of a muscle-spindle varies considerably. One of the longest simple spindles I have found measured $11.7 \mathrm{~mm}$., and the maximum breadth $.5 \mathrm{~mm}$., but an average size is from 2 to $4 \mathrm{~mm}$. in length, and 15 to $4 \mathrm{~mm}$. in breadth. It would seem to me that the size varies both with regard to age and to the length of the muscle, being longer in the adult than in the child, and in the longer muscles.

Frequency.-I have made no attempt to estimate the number of spindles in any given muscle, but an estimate has been made by Felix (11), who found seventy-nine in one biceps. They are, however, much more easily found in wasted muscle than in well-developed muscle, and more easily in the muscle of a child than in that of an adult, bence the muscle of a child dying of a wasting disease is a muscle in which it is easy to demonstrate the musclespindle.

Description.-The muscle-spindle is, as its name implies, spindle in shape (fig. 1), varying considerably in size. 


\section{PLATE I.}

Fig. 1.

Normal Spindle from Abductor Pollicis of Foot (Man).

$\begin{array}{lllllllll}\text { Length } & . & \ldots & \ldots & \ldots & \ldots & \ldots & \ldots & 6.65 \mathrm{~mm} . \\ \text { Breadth } & . . & \ldots & \ldots & \ldots & \ldots & \ldots & \ldots & 98 \mathrm{~mm} \text {. }\end{array}$

A nerve $(N)$ can be seen entering the equatorial region and this nerve contains a fibre whose breadth is $\cdot 01 \mathrm{~mm}$. A branch containing finer nerve fibres, $\cdot 004 \mathrm{~mm}$., lesves the nerve and enters the spindle further to the right. Another nerve (N) enters the spindle at the opposite pole, this also is composed of fine fibres-one measuring $006 \mathrm{~mm}$.

An artery (A) and a vein (V) can also be seen giving branches to the spindle.

$$
\text { Teased Specimen. Sihler's Method. }
$$

Magnified 8 diameters.

\section{Fia. 2.}

\section{Compound Spindte.}

$\begin{array}{lllllll}\text { Length of complete spindle } & \text {. } & \text {. } & \text {. } & \text {.. } & & 1.5 \\ \text { mm. }\end{array}$

Length betwoen entrance of nerves $\quad$.

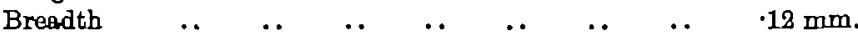

The pole of the second spindle enters the other spindle a little to the polar side of the equatorial region.

Compare figare 15, compound spindle in cross section.

$$
\text { Teased Specimens. Sibler's Method. }
$$

Magnified 24 diamoters.

Fic. 3.

Double Spindle.

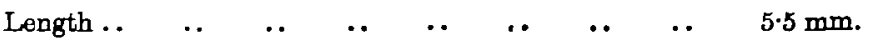

The pole of one spindle passes into the pole of the next, thas forming one continuous spindle-the nerve, however, enters the equatorial region of each spindle.

Teased Specimen. Sihler's Method.

Mlagnifled 7 diamoters. 
PLATE I.

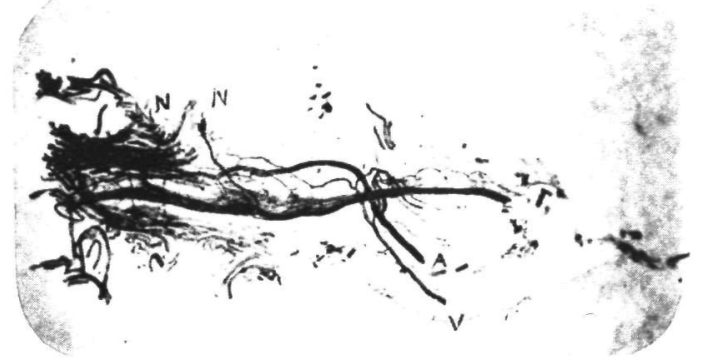

Fili, I.

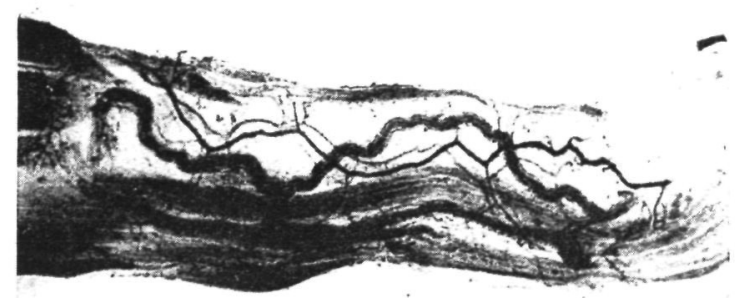

Fifi, 2

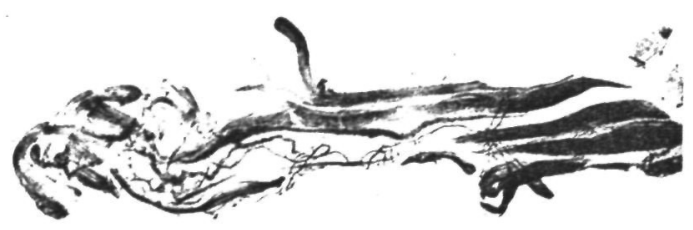

FIG. 3. 


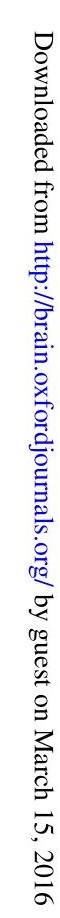


It is common to find several spindles in one plane of the muscles, and they are often found along the course of a nerve from which they receive their supply, and lie parallel to it (fig. 2). Spindles are sometimes found compounded of two simple spindles (fig. 2), but I have no teased specimen of more than two so compounded. Sherrington, however, describes a triple spindle, and Kerschner a quadruple (fig. 15). On the other hand, it is not uncommon to find one spindle joined at its end with another spindle (fig. 3), and that again may be joined to another; three in a row is the maximum number that I have found. In such a case each spindle receives its own nerve supply.

The relation which the muscle-spindle bears in position to the muscle fibre also varies. Firstly, the muscle-spindle may lie wholly in muscular tissue, the muscle fibre passing in at one end, and, after passing through the spindle, passing out at the other. Secondly, the spindle may lie partly in muscular tissue and partly in connective tissue. Thirdly, the musclespindle may lie wholly in the connective tissue, the contained muscle fibre being independent of external muscle fibres.

The essential portions of a muscle-spindle are-(i.) the muscle fibres, (ii.) the nerves and nerve-endings, (iii.) the sheath, (iv.) the blood vessels, (v.) the lymphatics and lymph spaces, (vi.) septa dividing the spindles into compartments.

The various parts will now be described in the above order.

The Muscle Fibre.-One or more muscle fibres enter one pole of a spindle; these fibres are smaller than the ordinary muscle fibres, being about $02 \mathrm{~mm}$. in diameter (the average extrafugsal fibre measuring about $06 \mathrm{~mm}$.) (fig. 4). The muscle fibres are well striated, and their striation is generally slightly coarser than the extrafusal fibres, ten striations occupying the same space as thirteen striations of the extrafusal fibres. As the muscle fibre or fibres pass towards the equatorial region of the spindle they become divided into many smaller fibres, some of these measuring only $008 \mathrm{~mm}$. (fig. 4). At a certain point the muscle fibre appears to lose its striation, and nuclei appear in the 
FIG. 4.

Normal Spindle from Biceps of Man.

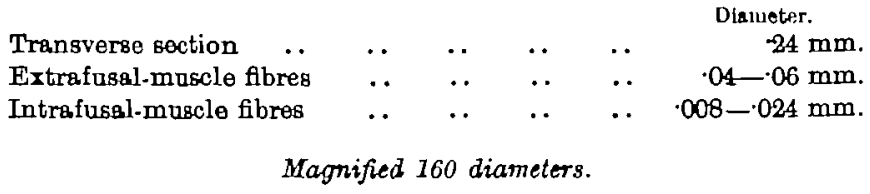

Fio. 8.

Normal Spindle in Longitudinal Section.

To show intramuscular nuclei, the nerve passing to this portion of the spindle is seen at $\mathrm{N}$.

The sheath is well seen, and the comparative size of the intrafusal (Mi) and the extrafusal $(\mathrm{Ne})$ muscle fibres is readily observable.

$\begin{array}{llllllll}\text { Intramuscolar nuclei } & \ldots & \ldots & \ldots & \ldots & \ldots & .006 \mathrm{~mm} \text {. }\end{array}$

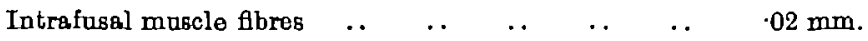

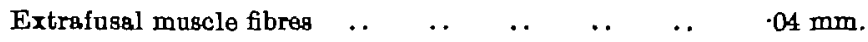

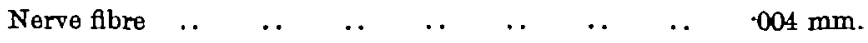

Lagnificd 110 diameters. 
PLATE II.

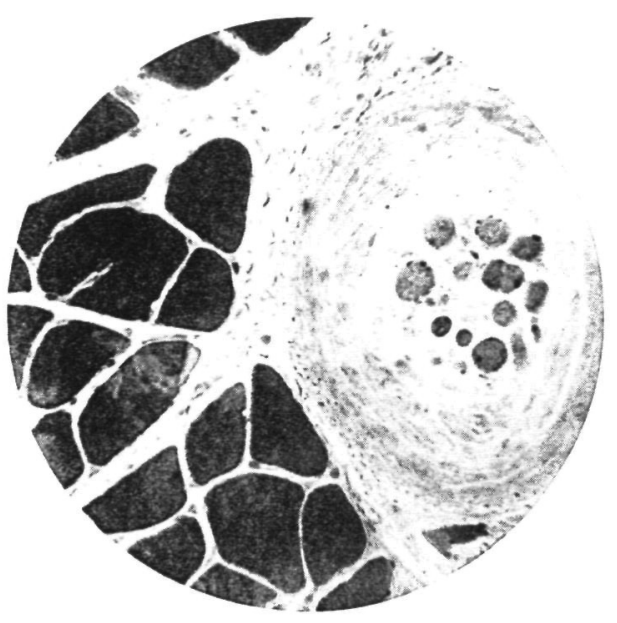

Fili. 4.

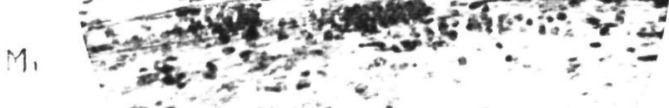



substance of the muscle fibres (fig. 5); these nuclei gradually increase in number till they completely fill the muscle fibre; then, after a short distance, they again become less numerous, and the muscle fibre again resumes its striation. The nuclei are rounded, have a diameter of about 006 mm. (fig. 5), they stain well with hæmatoxylin, and generally occur about the equatorial region of the spindle.

In the equatorial region of the spindle the muscle fibres usually lie to one side, as they do not completely fill the space, whereas at the proximal and distal ends the sheath closely envelopes the muscle fibres. The muscle fibres, after passing through these changes in the equatorial region of the spindle, pass to the distal end, where they become joined again and pass ont of the spindle. I do not believe that all fibres become so nucleated, for $I$ have seen muscle fibres pass through a spindle without losing their striation at any point. The number of muscle fibres in a spindle varies according to the different regions seen in section.

Nerves and Nerve-endings.-The nerve supply is always abundant; as a rule, at least two nerves pass to a musclespindle, the one at the equatorial region, the other at the proximal or distal end. It is not uncommon, however, to find four nerves entering a spindle at various points, two or more arising from a common nerve trank (figs. 1 and 10).

The largest nerve bundle usually enters the spindle at the equatorial region, and contains two or three fibres, the largest measuring about $008 \mathrm{~mm}$. The nerve bundles which enter toward lthe distal and proximal ends are generally composed of finer fibres, and sometimes of only a single fibre having a diameter of $004 \mathrm{~mm}$. or less.

These nerve fibres seem to terminate in various ways; as a rule, the large fibre which enters the equatorial region passes directly to the muscle fibre, and seems to lose itself in the nuclei of the muscle fibre above described (fig. 5) ; some fine fibres pass between the muscular fibres and terminate in such an organ as is figured in (fig. 7); others seem to have a spiral form. Others, again, form a fine plexus beneath or in the sheath of the spindle (fig. 6). So far 
PLATE III.

FIG. 6.

Normal Spirdle in Longitudiral Section.

Stained by modified Pal's Method to show nerve plexus toward the polar region of the spindle.

Letter $\mathrm{N}$ points to position of nerve termination, which is magnified in fig. 7.

Magnified 28 diameters.

Fig. 7.

Same as fig. 6 .

Under higher magnification to show nature of nerve ending within the spindle.

Diameter of terminal and bulb $(N)=008 \mathrm{~mm}$.

Magnifled 375 dianneters. 
PLATE III.

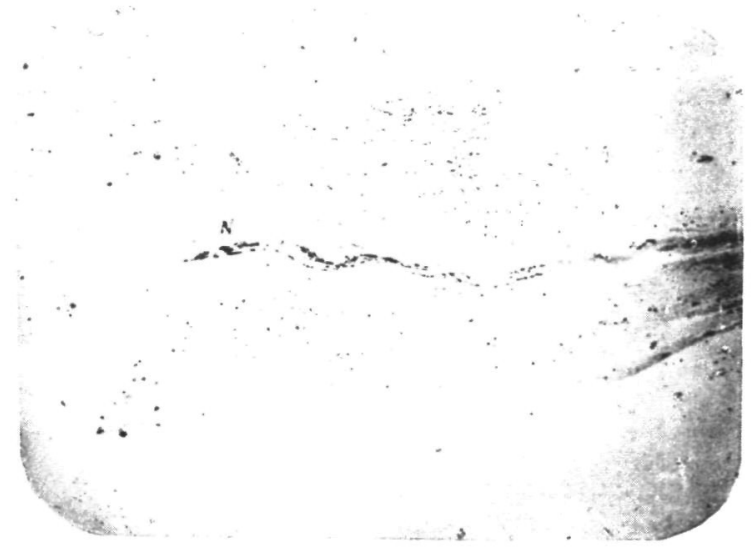

Fig. 6.

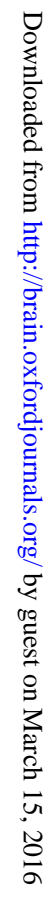

IU. 7 . 


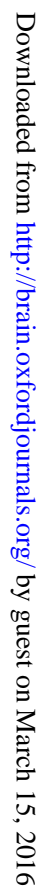


as my observations go, I have never seen a true motor end plate within a spindle. With regard to the number of nerve fibres within a spindle, one may see at times eight to ten in section. As a rule they are more numerous in the equatorial region than at the distal or proximal ends, but they are abundant in both situations.

Nerve Sheath.-Each nerve bundle passing to a spindle has a definite nerve sheath, composed of two or more layers. The nerve bandle passing to the equatorial region of the spindle has usually a sheath composed of eight or more laminœ, whilst the nerves entering at the distal or proximal ends have a sheath containing two to three layers. The sheath of the nerve passes directly into the sheath of the spindle as the nerve enters.

Spindle Sheath.-The sheath of the spindle resembles that of the nerve, and, as has been pointed out by certain authors, has the appearance of an onion in cross section. The laminœ are extremely fine, and possess elongated nuclei at intervals (fig. 14). At the equatorial region these laminæ are numerous, an average number being eight to ten; at the distal and proximal ends of the spindle the number of lamina become less, and eventually pass into the muscle sheath. The characters of the sheath are best studied in cross section.

Blood Vessels. -The muscle-spindle is supplied with arteries and veins, which most frequently enter the spindle near the entrance of the central nerve, although vessels may be seen entering the spindle at various points (fig. 1).

Lymphatic and Lymphatic Spaces.-A lymph space is situated about the equatorial region of the spindle, and occupies about the middle one-third of the spindle. In some of my specimens the space exists as such, whilst in others it is filled up by a granular material, which does not stain readily. Sherrington has been able to inject this space by injecting the lymphatics of the leg.

Lymphatic vessels can also be seen in the teased specimens running parallel to the course of muscle fibres, and forming junctions with other lymphatics.

Septa.-Between the groups of muscle fibres and nerves within the spindle, septa are often seen dividing the spindle 
PLATE IV.

FIG. 8.

Transverse Section from Tricep Mftuscle of Infantile Paralysis.

Two muscle spindles (S) are seen lying in completely atrophied areas.

$$
\text { Diameter of spindle }\left\{\begin{array}{l}
\text { (i) }=\cdot 25 \\
\text { (ii })=.17
\end{array}\right.
$$

Magnified 24 diametors.

Fig. 9.

One of the above spindles under higher magnification, eight muscle flbres of varying sizes can be seen within the spindle, and two nerve flbres (N) which are well stained by Pal's method.

Size of nerve fibres

Size of muscle flbre

Diameter of spindle

$$
\begin{array}{ccccccc}
. & \ldots & . & \ldots & \ldots & .01 \text { and } & .003 \\
. & \ldots & \ldots & \ldots & \ldots & . & .024
\end{array}
$$$$
\begin{array}{llll}
\cdots & \cdots & \cdots & \cdots
\end{array}
$$

Magnified 160 diameters. 


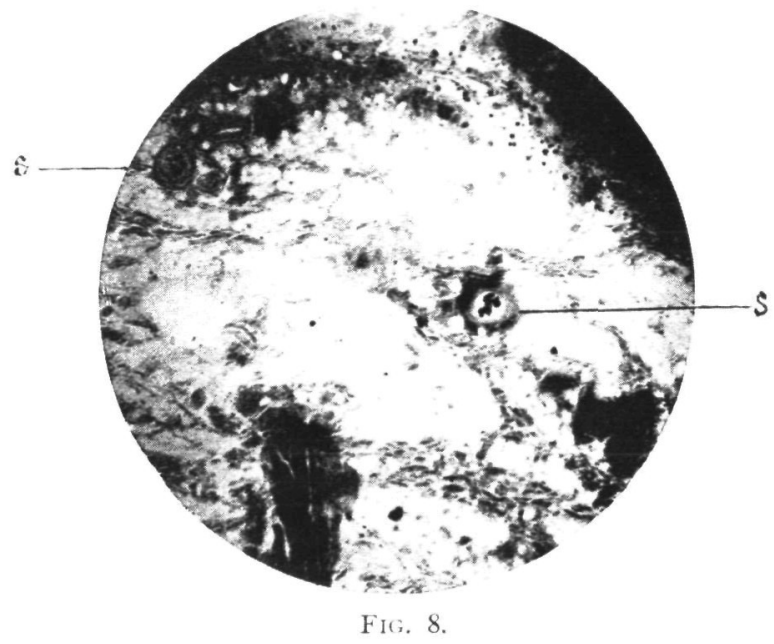

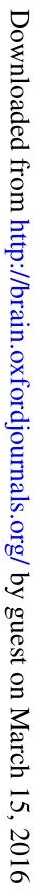




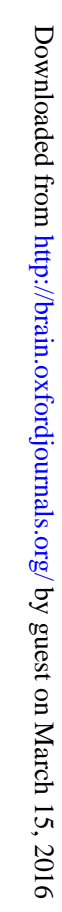


into two or more parts ; these septa are extremely fine, and pass into the sheath of the spindle.

TABLE I.

Normal Muscle.

\begin{tabular}{|c|c|c|c|c|}
\hline & Muscle. & $\begin{array}{l}\text { giso of Entra- } \\
\text { fogal Yuaclo } \\
\text { Flbres. }\end{array}$ & $\begin{array}{l}\text { 8lze of Bpindlo } \\
\text { (outside) }\end{array}$ & $\begin{array}{l}\text { Sise of Intra- } \\
\text { fusel Huaclo } \\
\text { Fbres. }\end{array}$ \\
\hline Man. & Biceps. & $06 \mathrm{~mm}$ & $\cdot 16 \mathrm{~mm}$ & .016 \\
\hline Child. & Biceps. & $.02 \mathrm{~mm}$ & $\cdot 16 \mathrm{~mm}$ & $\cdot 016$ \\
\hline
\end{tabular}

Measuremonts in Millimeters.

(V.) The Condition of THE MU8OLe-SPINDLE UNDER the Following Pathological Conditions.

(i.) Infantile paralysis ; (ii.) tabes; (iii.) myopathy (Leyden's form); (iv.) progressive muscular atrophy; (v.) peripheral neuritis; (vi.) injury to brachial plexus; (vii.) after section of sciatic in cats.

I do not propose to enter into the clinical history of these various cases, or to describe the pathological changes in the various muscles under examination, except in so far as they concern the muscle.spindle.

(i.) Infantile Paralysis.-I have been able to examine the muscle from six cases of infantile paralysis ; five of these were from museum specimens, and, having been preserved in spirit, conld not be stained by Pal's method. In the sixth case I was able to obtain the arm fresh, and have been able to treat it by the methods above described. In all the cases the paralysis was of long standing. In four of the cases, thirteen muscles were examined; all these muscles were considerably atrophied; some had apparently no normal muscle fibres left, yet in all of these the musclespindles could be demonstrated, and the intrafusal fibres were about the usual size (fig. 8). In the other two cases vol. $\mathrm{XX}$. 
the whole substance of the muscle was replaced by fat, and in these two specimens I was anable to find any spindles (only small pieces of these muscles were obtainable). What is the condition of the nerves entering the muscle-spindle? In answer to this question I was able to examine the muscles of case No. 6 by Pal's method, and it is found that not only the nerve entering the equatorial region (fig. 9) of the spindle, but also the plexus of nerves towards the polar ends, remain intact. The teased specimens give the same result, and also show that the striation of the intrafusal fibres is well preserved. In regard to infantile paralysis, it would seem probable that the muscle-spindle remains absolutely intact, both in regard to the intrafusal muscle fibres and in regard to the contained nerves. Table II. gives details of measurements and muscle examined.

(ii.) Tabes.-I have examined the muscles from three cases of tabes. In two of these I had only portions of the muscle, which were given to me after being in Müller's fluid for some time. These I examined by the usual methods, staining them with hæmatoxylin and by Pal's method, and, so far as the examination goes, it shows that the spindles are normal, both in regard to the intrafusal mascle fibres and the nerve supply. With regard to the third case, I have been able to examine it with greater care. Spindles have been teased out in the usual manner from the rectus femoris, vastus internus, and biceps of the arm. So far as the shape of the spindle and the nerves entering it is concerned, no change can be seen (fig. 10). The spindle does not, however, stain so readily with hæmatoxylin as does the normal spindle, and especially the equatorial region, which, as a rule, stains very deeply. The intrafusal nerve fibres, however, stain well. The striation of the intrafusal muscle fibre is well preserved. Examining the specimens of a spindle cut in longitadinal section, stained by Marchi solution, one finds, situated in the muscular fibre in the same position as the round cells which have been above described, evidence of degeneration (fig. 11). If now one examines the section stained by Pal's method, in order to find out if any degeneration hos occurred in the nerve fibre passing to this 


\begin{tabular}{|c|c|c|c|c|c|c|c|c|c|c|c|c|c|c|c|}
\hline 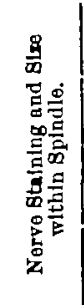 & 1 & 1 & 1 & 1 & 1 & I & 1 & 1 & 1 & 1 & 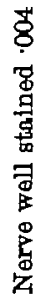 & 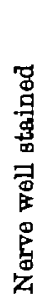 & 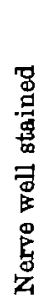 & 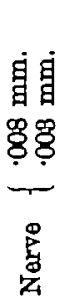 & 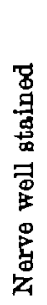 \\
\hline 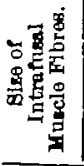 & $\stackrel{\infty}{7}$ & $\stackrel{\mathscr{9}}{\circ}$ & $\stackrel{0}{\mathscr{8}}$ & 电 & $\stackrel{9}{\circ}$ & 궁 & $\overrightarrow{9}$ & $\stackrel{9}{\circ}$ & 1 & 1 & 응 & $\stackrel{\infty}{\frac{9}{\varphi}}$ & $\overrightarrow{⿱ 艹}$ & $\stackrel{\infty}{\stackrel{\rho}{\rho}}$ & 옹 \\
\hline 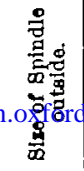 & $\underset{\text { oumgal }}{\text { 自 }}$ & S otg & / Gy & gues & $\underset{\mathrm{H}}{\text { 에 }}$ & 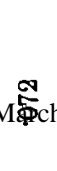 & h & 2ঞำ 6 & 1 & 1 & 多 & 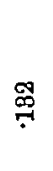 & $\ddot{7}$ & $\underset{-1}{\mathscr{8}}$ & $\stackrel{\infty}{\rightarrow}$ \\
\hline 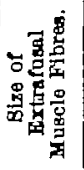 & $\begin{array}{l}\text { 亶 } \\
\text { 官 }\end{array}$ & \& & \&ै & 䒹 & 5 & 켱 & \% & 歺 & क & 1 & চ্ & 哭 & $\frac{0}{5}$ & 1 & 1 \\
\hline 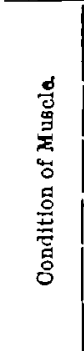 & 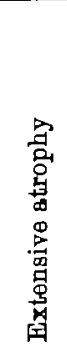 & 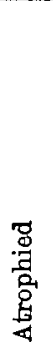 & 蔷 & 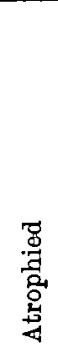 & 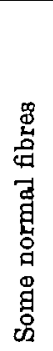 & 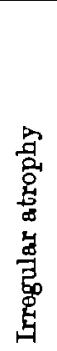 & 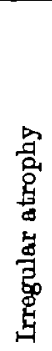 & 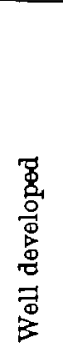 & 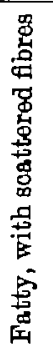 & 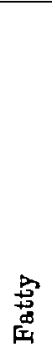 & 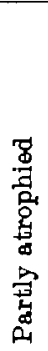 & 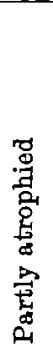 &  & 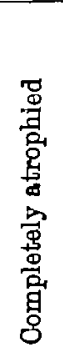 & 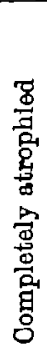 \\
\hline $\begin{array}{l}\text { 湢 } \\
\text { 品 }\end{array}$ & 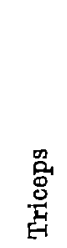 & 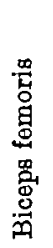 & 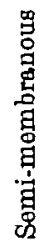 & 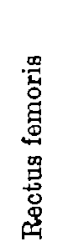 & 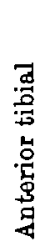 & 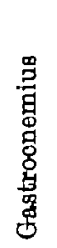 & $\underset{\stackrel{D}{0}}{\stackrel{5}{0}}$ & 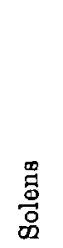 & 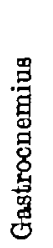 & 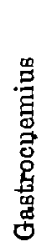 & 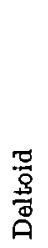 & 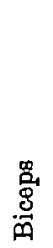 & 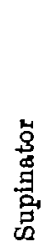 & $\underset{E}{\stackrel{g}{8}}$ & 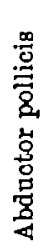 \\
\hline 急 & 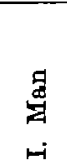 & 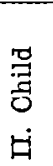 & & & 当 & & & & $\vec{\epsilon}$ & $\dot{D}$ & 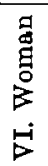 & & & & \\
\hline
\end{tabular}




\section{PLATE V.}

Fir. 10.

Normal Spindle from Vastus Internus (Tabes).

Teased Bpecimen. Sihler's Method.

$\begin{array}{llllllllr}\text { Length } & . & \ldots & \ldots & \ldots & \ldots & \ldots & \ldots & 11.9 \mathrm{~mm} \\ \text { Breadth } & . & \ldots & \ldots & \ldots & . . & . . & \ldots & .51 \mathrm{~mm} \text {. }\end{array}$

Nerve bundles are seen entering st four points, $1,2,3,4$.

No. 1. contains the largest nerve flbre measuring $008 \mathrm{~mm}$. and terminates about the equatorial region of the spindle.

The other nerves entering towards the poles are finer, varying trom 008 to $.006 \mathrm{~mm}$.

At the point marked 2 the nerve divides, one part can be seen passing to the motor nerve ending on the muscle flbres extrinsio to the spindle, the other enters the epindle.

Magnifled 7 diamators.

Fig. 11.

Spirdlo from the Roctus Fomoris (Tabes).

Cat in longitudinal sections to show degenerative change within the intrafugal muscle fibre. Stained in Marchl'e solution.

The degeneration is manifest by the deposit of fat in that portion of the intrafusal muscle fibre when it has been shown that intrafusal musole nuclei exist, the remaining portion of the muscle flbre remaining free.

$$
\begin{aligned}
& \mathbf{M} \mathbf{s}=\text { Ertrafusal mascle flbre. } \\
& \mathbf{M}=\text { Intrafusal musale fibre. } \\
& \mathbf{S h}=\text { Sheath. } \\
& \mathbf{D}=\text { Area of degeneration. }
\end{aligned}
$$

\begin{tabular}{llllllll} 
Breadth of spindle & $\ldots$ & $\ldots$ & $\ldots$ & $\ldots$ & $\ldots$ & $\ldots$ & \\
\hline
\end{tabular} $\begin{array}{llllllll}\text { Breadth of musale fibre } & \ldots & \ldots & \ldots & \ldots & \ldots & \ldots & 084\end{array}$

Magrified 150 diametors.

Fite. 18.

Spindle from Rectus Femoris (Tabos).

Cut in longitudinal section stained by Marchi-Pal Method to show that the nerve passing to the degenerate area within the spindle remains normal. The degenerated ares within the musale-fibre is apparent.

$\begin{array}{lllllllll}\text { Intrafusal muscle flbre } & \ldots & \ldots & \ldots & \ldots & \ldots & \ldots & 028\end{array}$

Magnifled 180 diamators. 


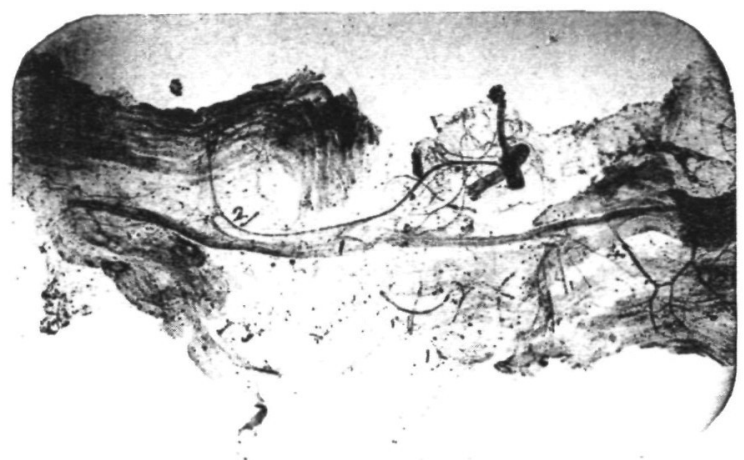

FIG. IO.

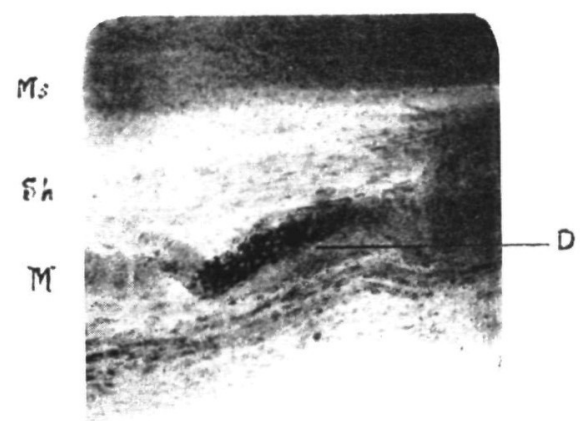

FIG. II.

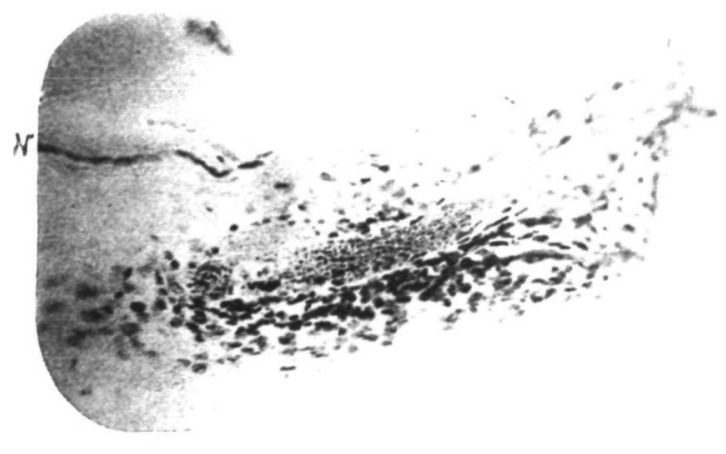

FIG. I 2. 

spot, one finds that the nerve fibre stains well, and shows no sign of degeneration (fig. 12). In a third specimen the same appearance is observable. It is difficult to prove that the above-described condition is traly pathological, but it is a condition which I have found in tabes, and not under any other circumstances. That changes should be found in the terminal organs, while the nerve lying between the ganglion cell and the terminal organ remains intact, seems to me not only a possible, bat a probable lesion, for it has been shown by Cattaneo (5) that, after section of the whole nerve, changes take place in the nerve termination within thirty-six to thirtyeight hours, while changes in the medullated portion of the nerve are extremely slow. So that in tabes, where one has a gradual degeneration taking place in the cells of the posterior ganglion, it is not unreasonable to suppose that changes take place at the extreme end of the neuron, without any change being manifest in the nerve itself. With regard to the other nerve-endings within the spindle, I find no evidence of degeneration (see Tables III. and IV.).

(iii.) Myopathy (Leyden form).-I have had the opportunity of examining the muscles from one case of myopathy, and in this case the following muscles were examined:Biceps (arm), pectoral major, pectoral minor, seratus, quadriceps, gluteus, and rectus abdominis. The sections have been prepared in the usual manner, except that there are no teased specimens. With regard to the condition of the spindle, it is remarkable, on examining the biceps, how numerous the spindles seem to be, as many as seventeen being found cut in one section. I have never found so many in any normal biceps, not even in the biceps from a boy of the same age, who died of phthisis. It was such an appearance which gave rise to the idea that these spindles were pathological bodies occurring in wasting muscles. This apparent increase is not so noticeable in the other muscles examined. With regard to the nerve supply, it is found that the nerves to the spindle all stain well by Pal's method, and the arrangement of the nerve fibres can be well studied. The striation of the muscle fibre is well marked within the spindle. In many of the spindles the intrafusal 
TABLE III.

Tabes.

\begin{tabular}{|c|c|c|c|c|c|c|}
\hline Case. & Hurcle. & 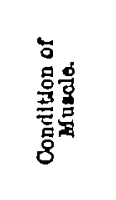 & 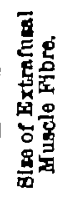 & 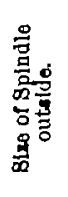 & 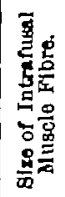 & $\begin{array}{l}\text { Nerve Sterolng } \\
\text { within Spindle. }\end{array}$ \\
\hline \multirow[t]{2}{*}{ I. Man } & Vastus Internus (left) & Normal & .048 & .072 & 015 & Well stained \\
\hline & Vastus Internus (right) & Normal & .048 & - & - & - \\
\hline II. Man & Vastus Internus & Normal & .06 & - & - & - \\
\hline \multirow[t]{3}{*}{ III. Woman } & Rectus femoris & Normal & .04 & .1 & .012 & Well stained \\
\hline & Vastus Internus & Normal & .04 & .24 & .018 & Well stained \\
\hline & Biceps & Normal & $\cdot 0.96$ & $\cdot 15$ & .02 & Well stained \\
\hline
\end{tabular}

TABLE IV.

Tabes (Tersed Specimens).

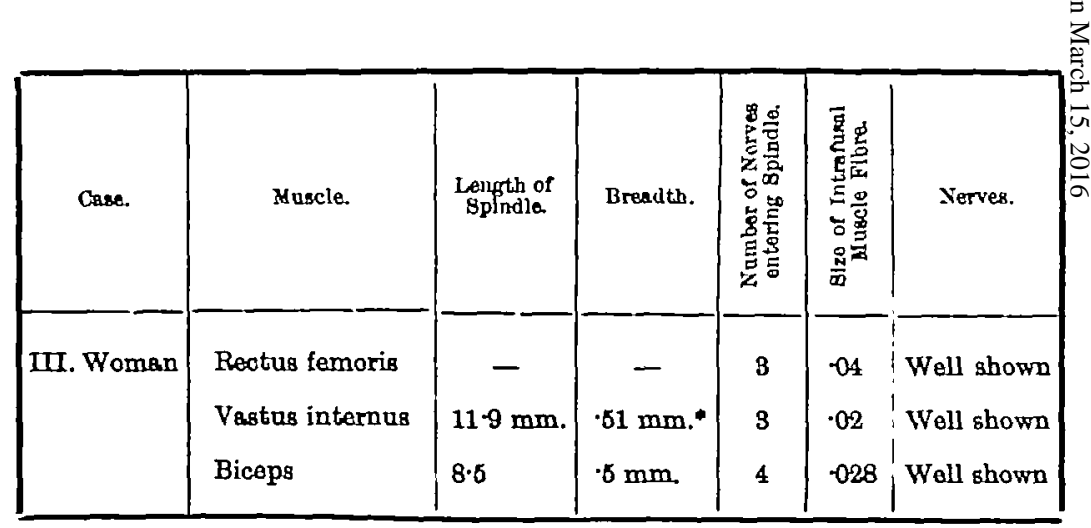

* Probably increased by pressure of cover glass. 
fibre is as large, and often larger, than the extrafusal fibre, the same condition is met with in the muscles of young children. In myopathy, then, the muscle-spindle remains without alteration (see Table V.), and (fig. 13 and 14).

(iv.) Progressive Muscular Atrophy.-The condition of the muscle-spindle in progressive muscular atrophy has been worked at by more than one author, viz., Pilliet, Blocq and Marinesco and Forster, and they agree that the spindle does not undergo alteration. Forster has further shown that the nerve to the spindle remains intact. I have had the opportanity of examining muscles from three cases of progressive muscular atrophy. In the teased specimens from these cases it is noticeable how the large nerve fibre passing to the spindle stands out against the surrounding atrophied fibres in the nerve. The spindle itself remains unaltered, the nerve fibres within the spindle are natural, and the intrafusal fibres preserve their striation. My observations, then, would agree with the above authors, viz., that the musclespindle remains unaltered in progressive muscular atrophy (fig. 16 and Table VI.).

(v.) Peripheral Neuritis.-I have had the opportunity of examining the muscles from only one case of peripheral neuritis, and in this case the atrophy of the muscles examined is not extensive; therefore it is a case of no great value in regard to the condition of the spindle. Three muscles were examined-the extensors of the wrist, the supinator longus, and the extensor longus digitorum. On microscopical examination of the first two named muscles, very little change is noted in the muscular structure. In the extensor longus digitoram there is a considerable amount of fat, some fibres considerably atrophied, others normal in appearance and size. In the extensor longus digitorum a muscle-spindle is seen in the middle of a completely atrophied area, the walls and muscle fibres appear to be normal, sections from Marchi's solution show no change, and staining with Pal's method shows the nerve fibres are normal. The otber muscles stained in a similar manner also show the normal spindle. In the teased specimens the intrafusal muscle fibres preserve their striation, the extrafusal muscle 


\section{PLATE VI.}

Fro. 18.

Transoerse Section of Biceps from a Case of Myopathy.

To show the prominence given to the muscle spindle by atrophy of the muscle-three spindles in transverse section are seen.

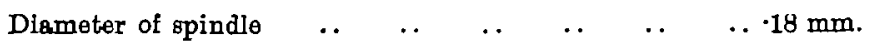

Magnified 44 diametors.

Fig. 14.

One of the above spindles under a higher power. The shesth is welf shown, the intrinsic muscle fibres are equal in size to the extrinsic (comparefig. 4). The varying size of the intrafusal muscle flbres is well shown.

$\begin{array}{lllllllll}\text { Diameter of epindle } & \ldots & \ldots & \ldots & \ldots & \ldots & \ldots & \cdot 18\end{array}$

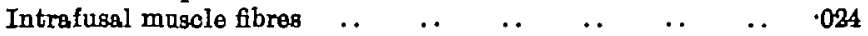

Magnified 180 diameters. 


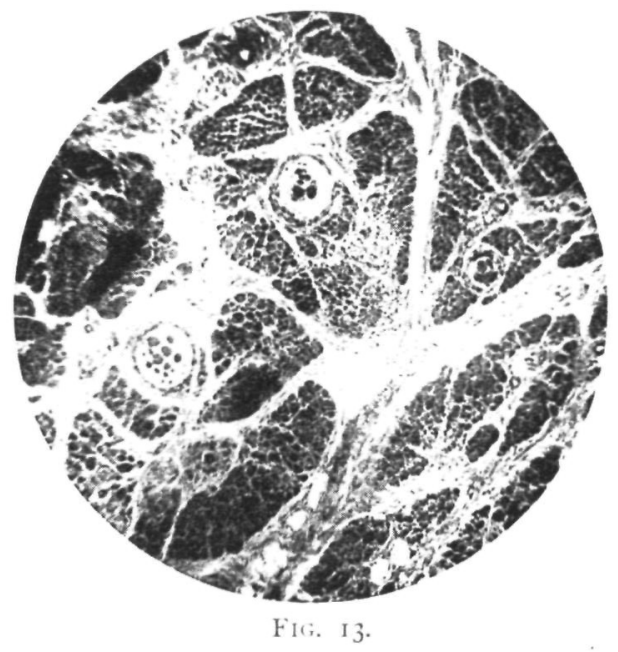

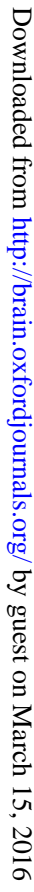

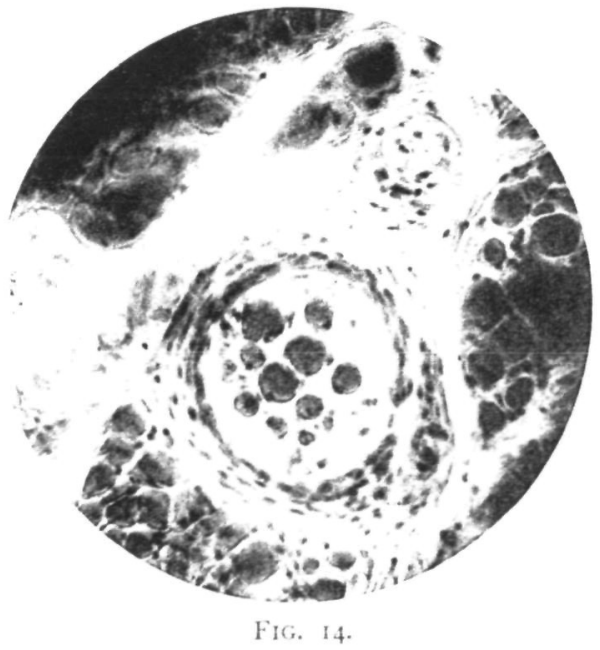



TABLE V.

Myopathy.

Boy aged 5 .

\begin{tabular}{|c|c|c|c|c|c|}
\hline Muscle. & $\begin{array}{l}\text { Conditton of } \\
\text { Huscle. }\end{array}$ & 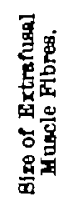 & 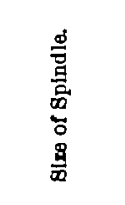 & 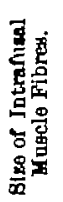 & $\begin{array}{l}\text { Nerve Staining within } \\
\text { Splndle. }\end{array}$ \\
\hline Biceps & Atrophied & $\left\{\begin{array}{l}024 \\
.008 \\
.048\end{array}\right.$ & $\cdot 180 \mathrm{~mm}$ & .038 & Nerve well stained \\
\hline Pectoralis major & Atrophied & .04 & $\cdot 160 \mathrm{~mm}$ & .02 & Nerve well stained \\
\hline Seratus & Atrophied & .0 .54 & $\cdot 12 \mathrm{~mm}$ & .024 & - \\
\hline Pectoralis minor & Atrophied & .096 & 一 & - & - \\
\hline Quadriceps & Atrophied & .024 & $\cdot 1 \mathrm{~mm}$ & .024 & Nerve well stained \\
\hline Glateus & Very fatty & .016 & - & - & - \\
\hline Reotus abdominis & Normal & .04 & - & - & - \\
\hline
\end{tabular}

TABLE VI.

Progressive Mruscular Atrophy.

\begin{tabular}{|c|c|c|c|c|c|c|}
\hline Oase. & Muscle. & 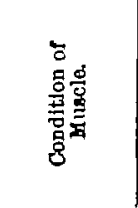 & 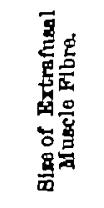 & 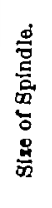 & 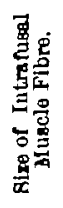 & Nerve Staining. \\
\hline I. Man & Biceps & Atrophied & .044 & $\cdot 14$ & .02 & Well stained \\
\hline II. Man & Abductor minimi digiti & Atrophied & $\cdot 04-008$ & 09 & -02 & Stained \\
\hline \multirow[t]{2}{*}{ III. Man } & Abductor minimi digiti & Atrophied & .012 & $\cdot 14$ & 016 & Well stained \\
\hline & Flexor brevis & Atrophied & .012 & $\cdot 16$ & .024 & Feebly stained \\
\hline
\end{tabular}




\section{PLATE VII.}

Fia. 15.

Compound Spirdle from Biceps of Myopathy.

Seen in Transverse Section.

Stained by Pal's Method.

This is probably an instance of a quadruple spindle, it is noticesble that the spindles are cut in varying parts of their course. Six divisions are seen, two of there (NN) contain nerve flbres as shown by the staining method, the other four contain muscle flbres. It is obvious that the poles of these spindles cannot lie on the same plane.

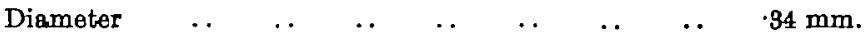

$\begin{array}{lllllllll}\text { Nerve fibre } & \ldots & \ldots & \ldots & \ldots & \ldots & \ldots & \ldots & .004 \\ \end{array}$

Magnifled 47 diametors. 
PLATE VII.

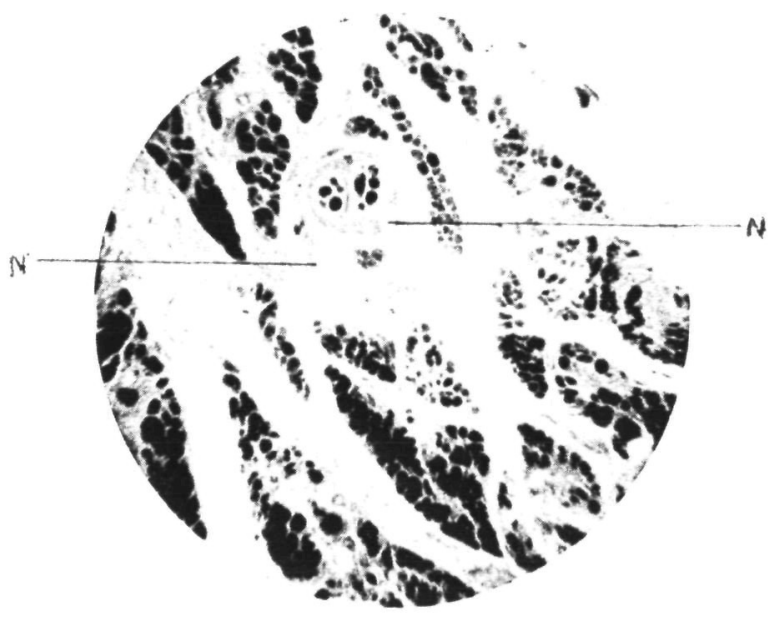



fibres have, in many fibres, lost their striation, and have a granular appearance. So far as one may judge from this case, one may say that in peripheral neuritis the spindle and its nerve remain intact after the muscle has become extensively atrophied; this is not, however, in agreement with Gudden's (16) statement (Table VII.).

(vi.) Injury to the Brachial Plexus, with Complete Loss of Motion and Sensations of a year's standing.-In this case, I have examined the biceps, triceps, muscles of the thumb, muscles of the little fingers, flexors and extensors of the wrist, and the ulnar and median nerves. All these muscles show most extensive atrophy; in many there are no recognisable fibres present, but in the biceps and triceps a few remain.

The ulnar and median nerves both show a very few fibres stained by Pal's method, which appear normal (these fibres measure about $\cdot 004 \mathrm{~mm}$, and one or two $008 \mathrm{~mm}$.).

What is the condition of the muscle-spindle ander these conditions? The spindle can be recognised in most muscles on careful examination, but it does not stand out in contrast to the surrounding tissue; all the spindles are small, the intrafusal muscle fibres atrophied, and the nerve fibres to the spindle do not stain by Pal's method. (There is one exception in a section of the triceps, one nerve fibre having taken the stain.)

In this case I have had considerable difficulty in teasing out the muscle-spindle; this I attribute partly to the fibrous increase in the muscle, and partly to the atrophy of the spindle. In the spindles which I have, however, teased out, the nerve is atrophied, the shape of the intrafusel muscle fibres can still be seen, but the transverse striation is almost completely lost and the fibres have a granular appearance; the usually darkly-stained portion in the equatorial region is absent, pointing to degeneration occurring in the intramuscular nuclei in this region. The spindle sheath can still be distinguished, but is not so distinct as normally. (Fig. 17).

It would seem, therefore, from the examination of the above, that atrophy of the spindle and its contained muscle fibres does take place, but at a much later period than the ordinary muscle fibre. 


\section{PLATE VIII.}

Fia. 16.

Muscle Spindle from Bypothenar Muscles of Progressive Muscular Atrophy.

To show unaltered condition of muscle spindle in this disease.

The intrinsic muscle flbres retain their normsl size and striation, while the surrounding muscle flbres have undergone extensive atrophy, being. reduced to $\frac{1}{10}$ of their normal sise.

Diameter of spindle $\quad \ldots \quad$.

Magrifled 180 diametors.

F'ig. 17.

Muscle Spindle from Hypothenar Muscles of a Case of Injury to Brachial Plexus.

Transverse section.

Two spindles are seen in transverse section lying in areas where extengive atrophy has taken place. The mascle fibres are smaller than normal, and appear shrunken.

Magnified 120 diameters. 


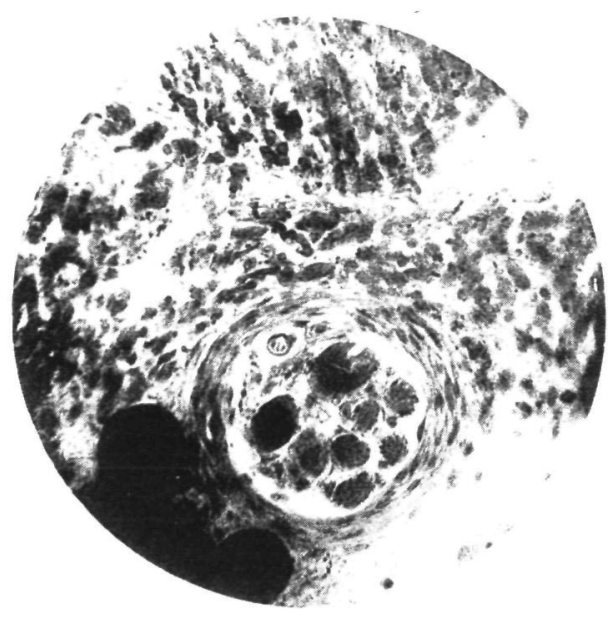

Fis. 16.
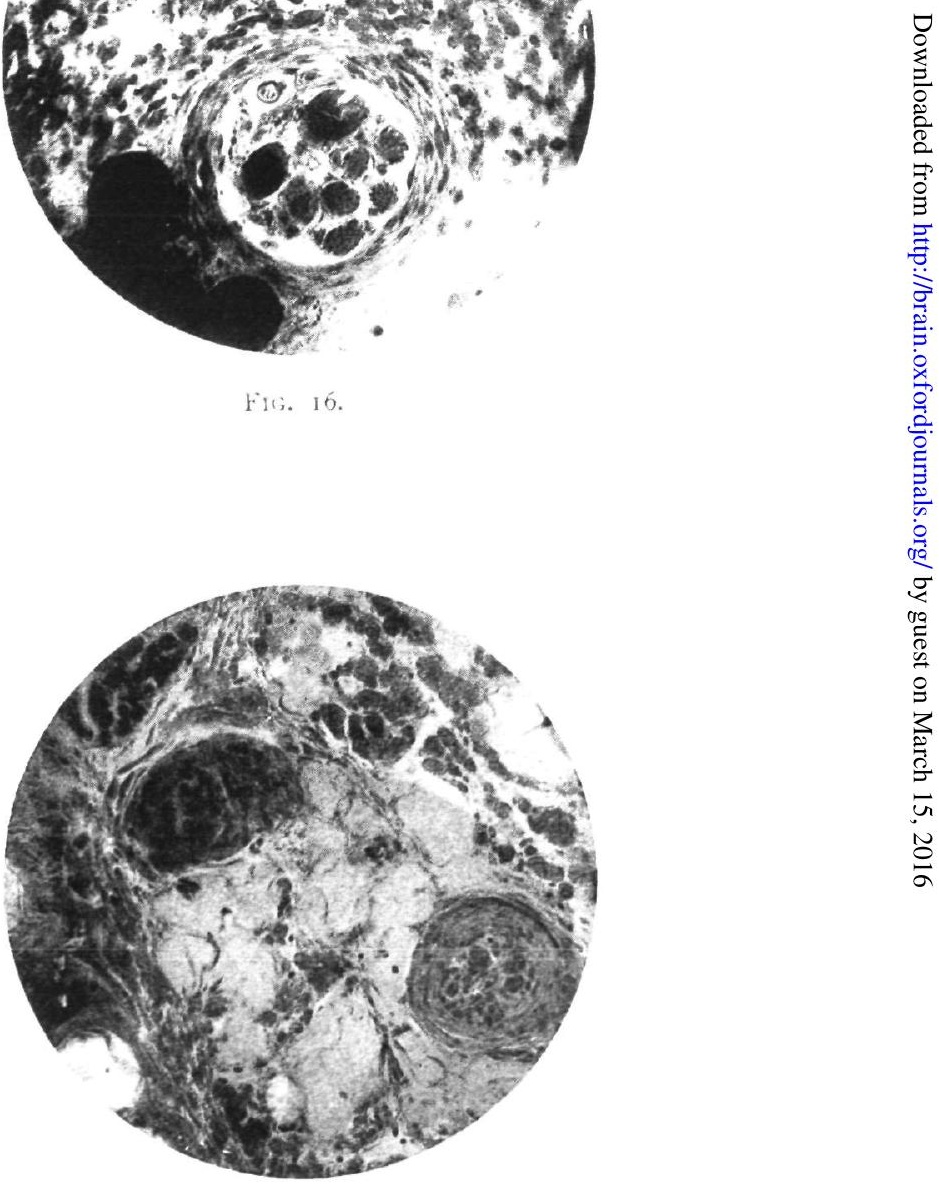

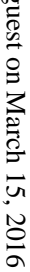

Fir. 17. 

TABLE VII.

Poripheral Neuritis.

Oase, Woman.

\begin{tabular}{|c|c|c|c|c|c|}
\hline Huacle. & Condition of Hurale. & 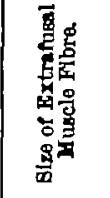 & 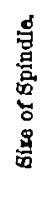 & 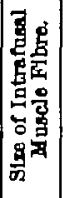 & Nerve 8talning. \\
\hline Extensors of wriat & Not much atrophied & .048 & $\cdot 2$ & .02 & Well stained \\
\hline Supinator longus & Irregular in size & $.08-.02$ & $\cdot 2$ & 016 & Well stained \\
\hline $\begin{array}{c}\text { Extensor longus digitorum } \\
\text { (leg) }\end{array}$ & Atrophied & $\cdot 1-008$ & $\cdot 18$ & .02 & Well stained \\
\hline
\end{tabular}

TABLE VIII.

Irjury to Brachial Plexus.

\begin{tabular}{|c|c|c|c|c|c|}
\hline Hascle. & $\begin{array}{l}\text { Oondition of } \\
\text { Mascla }\end{array}$ & 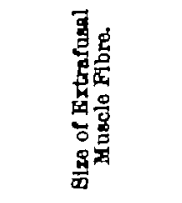 & 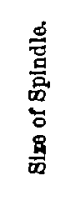 & 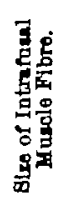 & Nerro staining. \\
\hline Biceps & Atrophied & $.06-.004 \mathrm{~mm}$ & .072 & 02 & Absent \\
\hline Triceps & Atrophied & $.048-004$ & -08 & .02 & $\begin{array}{l}\text { Present (one } \\
\text { fibre) }\end{array}$ \\
\hline Thumb musoles & Atrophied & $.02-.004$ & .08 & .012 & Absent \\
\hline Hypothener & Atrophied & $.02-.004$ & $\cdot 16$ & .012 & Absent \\
\hline Extensors of wrist & Atrophied & $.02-.004$ & .052 & -008 & Absent \\
\hline Elexors of wrist & Atrophied & $.02-.004$ & 01 & 016 & Absent \\
\hline
\end{tabular}


(xii.) Section of Sciatic in Cats ${ }^{1}$-three weeks, one month, two months, three months. - I have (thanks to the kindness of Dr. Risien Russell) had the opportunity of examining the gastrocnemius of four cats, at various times after complete section of the sciatic. The gastrocnemins of the cat is composed of two parts, one being white muscle fibres and the other red. I have examined muscles at the following times, after section of the sciatic: three weeks, one month, two months, three months, and have also examined

TABLE IX.

Cats-Section of Sciatic.

Muscle Gastrocnemius.

\begin{tabular}{|c|c|c|c|c|c|c|}
\hline Cat. & 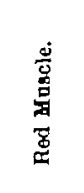 & 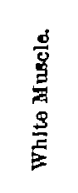 & 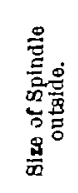 & 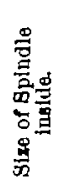 & 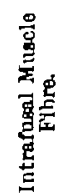 & 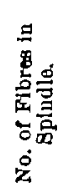 \\
\hline Normal & $\cdot 052$ & .047 & $\cdot 12$ & .08 & .0216 & 5 \\
\hline Cat I. (3 woeks) & .0412 & .096 & - & - & - & - \\
\hline Cat II. (1 month) & .0505 & .084 & $\cdot 16$ & .08 & 018 & 7 \\
\hline Cat III. (2 months) & .0256 & 0228 & $\int^{\cdot 1}$ & 064 & 0148 & 7 \\
\hline & & & 1.096 & -056 & 019 & 5 \\
\hline Cat TV. (9 months) & $\cdot 0184$ & 0162 & .048 & .032 & .019 & 7 \\
\hline
\end{tabular}

the normal muscle for comparison. In the normal mascle, the extrafusal fibres measure between 04 to $\cdot 06 \mathrm{~mm}$. The white fibres are somewhat smaller than the red. The intrafusal fibres measure about $02 \mathrm{~mm}$. Muscle-spindles occur in both forms of muscle, and to an equal extent, so far as I can judge. Table No. IX. shows the comparative size of the red and white muscle fibres at the various periods after section of the nerve, and also the size of the intrafusal muscle fibres. The

\footnotetext{
' From Experiments performed at University College Laboratory.
} 
table tends to show that atrophy takes place rather more rapidly in the white muscle fibres than in the red. I cannot say there is any definite atrophy in the intrafusal fibres. Sections stained by Pal's method show that the nerve to the spindle is degenerate in all cases. Striation is certainly wellmarked in the intrafusal fibre three months after section of the nerve, and Sherrington has shown that striation still persists 150 days after section of the nerve. I believe, however (as the case above related tends to prove), that degeneration does take place in the intrafusal muscle fibres if sufficient time is allowed to elapse.

\section{SUMmaRY.}

Historical.-Although certain observers, fifty years ago, seem to have described in muscle, bodies which we now recognise as muscle-spindles, Kölliker was, however, the first who gave a detailed description of these bodies, and soon afterwards Kühne added considerably to the description of Kölliker, and introduced the name "muscle-spindle" ; both these anthors regarded the spindle as a stage in the development of muscle. Then followed a series of authors who regarded the spindle as a pathological condition occurring in atrophied wuscle, and even as late as 1890 one author still regards them as pathological. Sachs, in 1874, fully recognised the sensory termination in muscle, but it was not till 1888 that Kerschner argued this sensory nature of the muscle-spindle, and suggested that their function might be connected with the sense of position. In the same year Cattaneo suggested that the muscle-tendon organs described by Golgi had a similar function, and proved experimentally that these bodies were connected with the posterior nerve roots. Then follow a series of authors working with normal and pathological materisl, some of whom adopted Keschner's view, others again adopting the view of Kölliker. Sherrington definitely proved, by degenerative experiments, that the nerve fibre from the muscle-spindle passes up in the posterior nerve root. All the later evidence points to the sensory 
nature of the muscle-spindle. The muscle-spindle has been shown to be a spindle-shaped body, composed of a sheath resembling the Henle sheath of a nerve; within this sheath are contained small muscle fibres, which at one point become densely nucleated, and lose their striation. Two or more nerve bundles enter the muscle-spindle, and terminate -(i.) in the muscle fibres, (ii.) between the muscle fibres, and (iii.) in the sheath. The spindle also contains bloodvessels and lymphatics. These spindles are found in nearly all muscles of the body, except the eye mascles, the intrinsic muscles of the tongue, and the diaphragm. It has been shown, in the present paper, that in infantile paralysis the spindle remains absolutely normal, although the surrounding muscle tissue undergoes complete atrophy. In tabes it is shown that certain changes take place in the termination of the nerves, the general structure of the spindle remaining normal. In myopathy, the spindle and its contained nerve are normal. In progressive muscular atrophy the spindle remains unaltered, and the same is probably true with regard to peripheral neuritis. Section or injury of nerve trunk leads to atrophy of the muscle fibre within the spindle, though it is probable that it takes a considerable length of time for changes to take place in the muscle fibre within the spindle.

In conclusion, I would wish to take this opportunity of thanking the pathologists of the National Hospital, Dr. Colman and Dr. Risien Russell, for the kind manner in which they have assisted me in my work. To many others I would also tender my thanks for having allowed me to make use of material which I needed for my work, and especially to Dr. Barlow, Mr. Willett, and Dr. Kanthack.

\section{REFERENCES.}

(1) BabrNski. (a) "Sur un cas de myélite chronique diffuse." Revue de Medecire, p. 246, 1884.

(b) "Sur la présence dans les muscles Stries de l'homme d'un système spécial constitús par des groupes de petites fibres musculaires entouées d'une geine lamelleuse." Saciete de Biologie, p. 629, December 18, 1886.

(c) "Fsiscenux neuro-musculaires." Archives de Medecine experimentate et d'anatomie pathologique, vol. i., p. 416, 1889. 
(2) Beark. (a) "Further Observation on the Distribution of Nerves to the Elementary Fibres of Striped Muscle." Transactions of the Royal Society, vol. 162, p. 889, 1862.

(b) "On the ultimate nerve fibres distributed to musele and some other tibsue." "Croonian Lecture," Proceedings of the Royal Society, vol. riv., p. 2229, 1865.

(3) Bloco \& Maringqo. "Sur lo morphologie des frisceaux neuro-musculaires." Saciete de Biologie, p. 398, 1890.

(4) Bremer. "Ueber die Muskelspindeln nebst Bemerkungen über Structur, Neubildang and Innervation der quergestreiften Muskelfasern." Archiv fïr mikroskopische Anatomie, Bd. xxii., S. 318, 1889.

(5) Cattanzo. "Organes nerveux terminanz mubculo-tendineux, lenr condition normale et leur manière de es comporter après la section des racines nervense et des nerfs spinanx." Archives Italiennes de Biologis, Tome x., p. 897, 1888.

(6) Ohristonarus \& Strössken. Beitrag zar Kenntniss der Muskelepindeln." Sitsungsberichto dor Kais. Akad. der Wissenschaft, Bd. 100, A. Bth. 3, S. 417, Wien, 1891.

(7) Doorkz. "Methylenbleutinction der motorischen Nervenendigungen in den Muskeln der Amphibien und Reptilien." Archiv für Mikroskopische Anatomie, Bd. 95, S. $805,1890$.

(8) Eıонновят. "Neuritis Fascians." Tirchow's Archiv, Bd. 112, S. 237, 1888.

(9) Ersentoнn. "Mittheilungen über anatomischen Befund bei spinaler Kinderlahmung." Tageblatt der 49. Versammlutng deutscher Natur. forscher und Aerste su Hamburg, S. 146, 1876.

(10) inRB. "Dystrophia muscularis progressiva." Deutsche Zeitschrift fir Nervenheilkunde, Bd. i., S. 19, 1891.

(11) FesIX. (a) "Theilungsersoheinungen an quergestreiften Muskeln der menschlichen Embryone." Aratomischer Anseiger, vol. iii., S. 719, 1888.

(b) Ueber Wachsthum der quergestreiften Muskulatnr nach Beobach. tungen an Menschen." Zeitschrift für wissenschaftliche Zoologie, Bd. 48, S. 224, 1889.

(12) Fonster. "Zur Kenntniss der Maskelspindeln." Virchow's Archiv, Bd. 187, S. 121, 1894.

(13) Frafaker. "Ueber Verändernagen quergestreifter Muskeln bei Phthisikern." Dirchow's Arclivi, Bd. 78, 8. 880, 1878.

(14) V. Frarque. "Beitrïge zur Kenntniss der Muskelknospen." Verhandlungen der physilial. medicin. Gesellschaft su Wilreburg, Bd. xxiv., 1890.

(15) GoLgI, "Annotazioni intorno all'Istologia normal e Patologica dei muscoli voluntari." Archivio per le scierze Mediche, vol. v., 1882.

(16) GodDex. "Klinische und anatomische Beiträge zur Kenntniss der multiplen Alkoholnearitis nebst Bemerkungen über die RegenerationsVorgänge im peripheren Nervensystem." Archiv für Psychiatrie und Nervenkrankheiten, Bd. nrviii., S. 648, 1896.

(17) KerschNRR (a) "Bemerkungen tber ein besonderes Muskelsystem im willkürlichen Maskel." Anatomischer Anteiger, S. 126, 1888.

(b) “Beitrag zor Kenntniss der sensiblen Endorgone." Anatomischer Anzeiger, S. 288, 1888.

VOL. XX. 
(c) "Ueber Muskelspindeln." (v. Ebner.) Verhandlungen der anato mischen Gesellschaft für die sechsto Vorsammlung, 8. 85. Wien, 1892.

(d) "Ueber die Fortschritte in der Erkenntniss der Muskelspindeln." Anatomischer Ansoiger, S. 449, 1899.

(18) KöLIIKER. (a) "Untersuchungen über die letrten Endigungen der Nerven," Zeitschrift filr wissonschaftliche Zoologie, Bd. xii., $\mathbf{8 .}$ $149,1868$.

(b) "On the Termination of Nerves in Muscles." "Oroonian Leotures." Praceedings of the Royal Saciety, vol. 12, p. 65, 1862.

(c) Handbuch dor Gewebelehre, Bd. i., S. 894, 1889.

(19) Künos. (a) "Ueber die Endigung der Nerven in den Maskeln." Virchow's Archiv, Bd. 27, S. 508, 1869.

(b) "Die Muskelspindeln," Virchow's Archiv, Bd. 28, в. 528, 1863.

(c) "Ueber die Endigung der Nerven in den Nervenhägeln der Muskeln." Virchow's Archiv, Bd. 30, 8. 205, 1864.

(20) MaYs. " Histophysiologische Untersuchungen uber die Verbreitang der Nerven in den Mnskeln." Zeitschrift filr Biologie, Munchen, Bd. zx., S. $449,1884$.

(21) Mreschen Archiv fur Anat. Phys. und Wissen. Med., 8. 69, 1849., (ref.) Verhandlungen der naturforschenden Gessellschaft in Basel S. $198,1849$.

(22) MmLbaoher. "Beitrag zur Pathologie des quergestreiften Muskels." Deutsches Archiv für klinische Medicin, Bd. xx., S. 304, 1882.

(23) Perringsonko. "Die Entwickelung der quergestreiften Muskelfasern aus Muskelkernen." Virchow's Archiv, Bd. 27, S. 116.

(24) Pilliet. "Sur des nerfs neuro-musculaires a enveloppe semblable d celle des corpusoules de Pacini." Societe de Biologie, p. 813, 1890.

(25) Rarvize. "Histologie du systìme nervear." Tome ii., p. 319, 1878.

(26) RoTr. "Ueber neuro-musculaere Stämmchen in den willkürlichen Maskeln." Centrablatt filr die medicinische Wissenschaft, 8. 129, 1887.

(27) RUPFINI. (a) "Sur la terminaison nerveux dans les faiscesax mubculairas et sur leur signiflcation physiologique." Archive Ital. de Biologio, Tome xviii., p. 106, 1893.

(b) "Considerazioni critiche sui racenti studi dell apparato nervoso nei fusi muscolari." Anatomischer Anseiger, Bd. ix., S. 80, 1894.

(28) SACHB. "Physiologische und anstomische Untersuchungen uber die sensiblen Nerven der Muskeln." Archio filr Anat. Phys. und Wisen. Med, S. 175, 491, 645; 1874.

(29) SaxtessoN. "Einige Worte über Neubildung von Muskelfasern and über die sogennanten Muskelspindeln." Verhandlungen des biologischen Vereins in Stockholm, Bd. iii., Abt. 9, S. 26, 1890. Jahresborichte dor Anatomie und Physiologie, Bd. 19, S. 121, 1890.

(B0) SHERATrgtos. "On the anatomical constitution of nerves of akeletal muscles." Journal of Physiology, vol. xvii., p. 237, 1895.

(31) V. ВІввог. Zoitschrift für wissenschaftliche Zoologie, Bd. v., S. 199, 1853.

(82) Strmerring. (a) "Kurze Bemerkung zu der von Eichhorst sogenannten Neuritis fasciens." Archiv fur Psychiatrio, Bd. rix., 8. 824,1888 . 
(b) "Ein Fall von gummőser Erkrankung der Hirnbasis mit Betheiligung des Chiasme nervorum opticoram." Archiv fir Psychiatrie, Bd. xix., 8. 423, 1888.

(c) " Ein Fall von Altoholneuritis mit hervorragender Betheiligung des Maskelepparate nebst Bemerkungen über das Vorkommen neuromusculearer Btämmohen in der Muskulstur." Charite Annalen, S. $449,1889$.

(38) Strmer (a) "Ueber eine leichte und sichere Methode die Nervenendigang an Muskelfasern and Gefässen nechzuweisen." Archiv fïr Aratomie und Physiologie, 1895. Physiologische Abthoilung, S. 202.

(b) "Ueber Muskelspindeln and intra-musculare Nervenendigungen bei Schlangen und Fröschen." Archio filr mikroskopische Anatomie, Bd. 46, S. 709, 1895.

(94) V. Thanhofmer. "Ueber die Nervenendigungen der quergestreiften Maskelfasern und über Re- and Degeneration derselben im lebenden Körper." Anatomischor Aneoiger, 8. 636, 1898.

(95) TrNNCHEse. "Contribution \& la connaissance des faiscesur musculaires." Archive Ital. de Biologie, Tome riv.; p. 221, 1891.

(96) Vorkmaxk. "Regeneration quergestreifter Muskelgewebe beim Mensohen und Bäugethiere." Borträge zur Pathologischen Anatomie, Bd. rii., 8. 820, 1893.

(87) Wrismakx. "Ueber das Wachsen der quergestreiften Muskeln nach Beobschtangen am Frosch." Zeitschrift filr rationells Medicin, Bd. х., 8. 268, 1861.

(98) Weiss \& DUTIL. "Rocherches sur le faisceau neuro-musculaire." Archives de Physiologis (Bouchard), Tome vili., p. 868, 1896.

(99) Wh8tPhaL. "Zwei Schwestern mit Pseudo-hypertrophio der Muskeln." Charite Annalon, S. 458, 1887. 